\title{
GALLEGOS, HIDALGOS, Y PICAROS EN LA ESPAÑA DEL SIGLO XVII. ESTEBANILLO GONZALEZ Y SALVATIERRA DE MIÑO
}

\author{
por \\ JESUS-ANTONIO CID
}

La obra que cierra -con broche de oro, según Juan Goytisolo- el ciclo de la picaresca española fue publicada por un cierto Estebanillo González que confiesa ser natural de Salvatierra de Galicia, en la actual provincia de Pontevedra. Sin embargo, el autor de la biografía que se narra en ese extraño libro, La vida y hechos de Estebanillo González, hombre de buen humor (Amberes 1946), no fue el mismo Esteban González que la protagoniza y que dice haberla compuesto. Esa es, al menos, la conclusión a la que hemos llegado en trabajos anteriores, en los que postulamos un proceso de composición más complejo que el que vendría dado por la presunta identidad del autor, el personaje, y la voz narradora, que coincidirían en una misma y única persona, según quiere hacerse creer en el propio libro ' ${ }^{2}$. Muy al contrario, el

' J. A. Cid, La personalidad real de Stefaniglio. Documentos sobre el personaje y presunto autor de La vida y hechos de Estebanillo González, Criticón, 47 (1989), 7-28; Máscaras y oficio en un escritor del Antiguo Régimen: Estebanillo González Gabriel de la Vega [1980-81], RDTP XLIII, Homenaje a C. Casado (1988), 175-195; "Centauro a

"CUADERNOS DE ESTUDIOS GALLEGOS", Tomo XL, Fascículo 105, Santiago 1992. 
autor verdadero resulta ser -en nuestra hipótesis- un oscuro escribano, Gabriel de la Vega, impenitente escritor por oficio de diversas crónicas en verso de las campañas militares de Flandes entre 1637 y 1643 . Ahora bien, el que la obra resulte ser una pseudo-autobiografía, un libro cuyo verdadero autor es persona distinta de quien pretende serlo, no implica que la biografía allí narrada sea la de un personaje ficticio, como han supuesto algunos estudiosos. Nuestra tesis básica es que sobre el cañamazo de unos hechos reales vividos por un personaje histórico se urdió una narración que somete a eleboración literaria esos mismos hechos, aunque sólo esporádicamente la voluntad de estilo y el deseo de hipercaracterizar figuras o situaciones alteran sustancialmente la realidad del personaje y su biografía.

La existencia del Esteban González, natural de Salvatierra, recriado en Roma, servidor y bufón del hermano de Felipe IV y del general Piccolomini en Flandes, es ya un hecho comprobado documentalmente ${ }^{2}$. Distintas fuentes de archivo han permitido localizar al personaje en escenarios geográficos y momentos históricos que coinciden con los que se exponen en La vida y hechos de Estebanillo González: Palermo en 1622, Flandes en 1638-1640, Silesia y Bohemia durante la campaña contra los suecos en 1642, etc. Mi objetivo ahora es precisar con mayor detalle los datos que se refieren al nacimiento de Esteban González en Salvatierra y examinar en qué medida la documentación de época permite corroborar la veracidad de lo que se afirma en el libro de 1646. También nos interesará aquí observar la vigencia de ciertos lugares comunes sobre Galicia y los gallegos en la España del XVII, según eran asumidos (irónicamente o no) en la biografía -de un gallego- tan autodenigratoria como resulta ser La vida y hechos de Estebanillo González.

lo pícaro" y voz de su amo: Interpretaciones y textos nuevos sobre La vida y hechos de Estebanillo González, I: La Sátira contra los monsiures de Francia y otros poemas de 1636-1638 [1974], Criticón, 47 (1989), 29-76; "Centauro a lo pícaro"..., II: ¿Burla privada o apología pública de Ottavio Piccolomini? [1974]; en prensa en la Nueva Revista de Filología Hispánica; La Europa de Estebanillo González y la Monarquía hispánica, Revista de Occidente, núm. 109 (junio 1990), pp. 49-80. Estos trabajos se extractan en el estudio introductorio de la nueva edición de la obra que he preparado junto con A. Carreira (Madrid: Cátedra, 1990; Letras Hispánicas, núms. 309 y 312), vol. I, pp. XIVCXXXVI. Las referencias que haremos al texto del Estebanillo González remiten a esta edición.

${ }^{2}$ V., en especial, La personalidad real de Stefaniglio..., cit. supra. 


\section{1. ¿Mi patria es común de dos?}

$\mathrm{Al}$ comienzo del libro el narrador es fiel a la pauta, aprendida en las novelas picarescas anteriores, que imponía abrir el relato con la exposición de los orígenes familiares y el nacimiento del protagonista:

Prométote, lampiño o barbado lector [...] que, si no lo has por enojo, sólo sé de mi nacimiento que me llamo Estebanillo González; tan hijo de mis obras que si por la cuerda se saca el ovillo, por ellas sacarás mi noble decendencia. Mi patria es común de dos, pues mi padre, que esté en gloria, me decia que era español trasplantado en italiano y gallego enjerto en romano, nacido en la villa de Salvatierra y bautizado en la ciudad de Roma: la una cabeza del mundo, y la otra rabo de Castilla, servidumbre de Asturias y albañar de Portugal; por lo cual me he juzgado por centauro a lo pícaro, medio hombre y medio rocín: la parte de hombre por lo que tengo en Roma, y la parte de rocín por la que me tocó de Galicia (I, 31-33).

Aparece ya de entrada la primera sátira contra Galicia, juzgada, de acuerdo con las caracterizaciones usuales en el momento, como un territorio rústico y semisalvaje. Sus habitantes, en justa adecuación al medio, son también animalizados. La denigración adquiere especial violencia, reforzada por ser confesión de parte de quien se reconoce gallego y por el contraste con Roma, arquetipo de civilización, urbanidad y cultura. El bautismo romano supone una segunda identidad espiritual, superpuesta, que redime al protagonista del pecado original de su animalidad -gallega- primaria. La antítesis inicial entre Roma y Salvatierra -cabeza del mundo / rabo de Castilla- se alarga a tríada, de acuerdo con una pauta estilítica constante en toda la obra, y Salvatierra es definida como rabo de Castilla, servidumbre de Asturias y albañar de Portugal. La intensidad del insulto a la propia patria no tiene parangón en la literatura coetánea, sobre todo si se tiene en cuenta que "servidumbre", además de su sentido jurídico usual de derecho de paso o camino entre heredades, significaba también "letrina", acepción que con seguridad el autor tenía presente y que hace pareja con el "albañal" que sigue inmediatamente en el texto.

Acto seguido, sin embargo, el autor da un quiebro al modelo de la narración de orígenes consagrado por la picaresca, y se permite hacer que el protagonista ponga en duda el relato que acaba de exponer. Era, efectiva-

"CUADERNOS DE ESTUDIOS GALLEGOS", Tomo XL, Fascículo 105, Santiago 1992. 
mente, inverosímil la historia del nacimiento en Galicia y el bautismo en Roma, por más que algún crítico haya visto ahí apoyos para argumentar en favor de un origen converso o, incluso, criptojudío, de Estebanillo, creyendo que en el bautismo en tierra ajena, y tan lejana, subyace la confesión de una fuga apresurada de la familia ${ }^{3}$. En cualquier caso, al narrador le era fácil cuestionar un relato que descansa sólo en una autoridad de persona interpuesta, aunque sea la del padre del protagonista, y aprovecha la ocasión para lanzar otra andanada contra Galicia y los gallegos. Al contraste entre civilización y barbarie -Roma y Salvatierra- que para el autor equivale a la oposición entre la ciudad y el campo, y a algunas precisiones sobre la villa natal -las únicas que se dan en la obra y casi indiferenciables de tópicos extensibles a toda Galicia-, se añaden ahora unas referencias culturalistas que en el contexto devienen pura parodia: el incendio de Troya soñado por Hécuba y la contienda entre las ciudades griegas que se disputaban el honor de ser la patria de Homero:

Ello si va a decir verdad, aunque sea en descrédito de mi padre, jamás me he persuadido a que esto pueda ser como él lo afirmaba, porque no tuvo mi madre tan depravado el gusto que me había de abortar del derrotado bajel de su barriga en el aguanoso margen del Miño, entre piélagos de nabos y promontorios de castaños, y en esportillas de Domingos, Brases y Pascuales, pudiéndome parir muy a su salvo en las cenefas y galón de plata de la argentada orilla del celebrado Tíber, entre abismos de deleitosos jardines y entre montes de edificios insignes, y sobre tapetes escarchados por la copia de Amaltea, cunas y regazos de Rómulos y Remos. Y cuando tuviera tan mal capricho y tan hecha la cara al desaire que me bostezara de su gruta oscura a ser, con perdón, gallego, y a que perdonara a Meco como todos sus pasados, echaría la soga tras el caldero y donde me parió me daría bautismo, si ya no es que soñase como Hécuba, reina de Troya, que de su vientre había de salir una llama que fuese voraz incendio de Galicia; y después, viendo el mostruo que había nacido del cofre de su barriga, se acogiese a Roma por todo [...]

$\mathrm{Y}$ finalmente, para que no padezca detrimento mi natividad, ni

\footnotetext{
${ }^{3}$ Cf. M. G. Chiesa, Estebanillo González e gli ebrei, Rassegna Iberistica 11 (ottobre 1981), 3-20.
}

"CUADERNOS DE ESTUDIOS GALLEGOS", Tomo XL, Fascículo 105, Santiago 1992. 
ande mi patria en opiniones, ni pleiteen Roma y Galicia sobre quién ha de llevar mi cuerpo cuando llegare su postrimero fin, convido a los curiosos al valle de Josafad, el día que el ángel, pareciendo viento de mapa, tocare la tremenda trompa, a cuyo eco horrible y espantoso se levantarán pepitorias de huesos y armaduras de tabas; que entonces, por ser tiempo de decir verdades, presumo que no la negarán mis padres, con que todos saldrán de sus dudas, y yo sabré si soy vasallo de un Sumo Pontífice o de un Rey de España, Monarca de un nuevo mundo; y a quien Dios se la diere, san Pedro se la bendiga. Y en el ínterin haré como hasta aquí he hecho, que ha sido a dos manos, como embarrador, siendo español en lo fanfarrón y romano en calabaza, y gallego con los gallegos y italiano con los italianos, tomando de cada nación algo y de entrambas no nada (I, 35-38).

Entre un cúmulo de alusiones cultas y frases hechas de acarreo, literales (la soga tras el caldero, a quien Dios se la diere..., A Roma por todo) o adaptadas (pleitear Roma con... Santiago, con perdón,... gallego, ...perdonar al Meco $)^{4}$, se nos describe aquí la presunta villa natal del pícaro como situada en la margen del Miño, y como fértil en castañas y nabos, lo que lugares comunes aparte- no dejan de ser observaciones precisas.

Las aparentes dudas del narrador sobre el lugar de nacimiento del personaje se revelarán, en el transcurso de la obra, como simple artificio literario para relativizar o atenuar en estas páginas iniciales su calidad de gallego. Es posible que tal calidad parezca literaria y funcionalmente equiparable a los orígenes sociales infames del antihéroe arquetípico de la picaresca, como ha postulado Avalle-Arce, por más que la equivalencia diste mucho de ser exacta y sea, en cualquier caso, desmentida más adelante por el propio autor ${ }^{5}$.

\footnotetext{
${ }^{4}$ Cfr., en nuestra edición, las notas I.15 y ss.

${ }_{5}^{5}$ J. B. Avalle-Arce, El nacimiento de Estebanillo González, NRFH XXXIV (1985-86), 529-537. Incluído en Lecturas (Del temprano Renacimiento a Valle Inclán) (Potomac, Maryland: Scripta Humanistica, 1987), 34-42. Según Avalle-Arce, Con muy hábil juego de manos, Estebanillo nos escamotea la infamia (factor estructurante de la picaresca) y la sustituye por la burda y sangrienta comicidad del galleguismo (p. 537). Disiendo de la interpretación del galleguismo como factor estructurante sustitorio de la infamia ab origine, aunque concuerdo enteramente en la inexistencia de tal infamia en Estebanillo. Creo que Avalle-Arce exagera un tanto cuanto cuando dice que se entristece su ánimo filológico al notar que no se ha prestado la menor atención a este aspecto capital -la ausen-
}

"CUADERNOS DE ESTUDIOS GALLEGOS", Tomo XL, Fascículo 105, Santiago 1992. 
En efecto, el personaje Esteban González irá asumiendo progresivamente, y ya sin ironías, su identidad de gallego; y aunque hasta muy tarde no renuncie a calificarse de gallego-romano, como reflejo de su doble crianza, la importancia relativa de los términos de su autodefinición experimentará al final una inversión absoluta.

Ya avanzado el libro, se relata el primer y único contacto real del pícaro con Galicia. El episodio empieza con una peregrinación a Compostela en compañía de otros dos pseudo-romeros, francés uno y genovés el otro. El elogio a la capital gallega por excelencia no puede ser más explícito, igual que la confesión de su identidad nacional: Llegamos a la ciudad de Santiago, que, por que no me tenga por parte apasionada por lo que tengo de gallego, me excuso de decir lo mucho que hay en ella que poder alabar (I, 176). Estebanillo se separa después de sus compañeros en el arte de la bribia y viaja en solitario hasta Pontevedra, villa muy regalada de pescado, adonde como ballena racional da fin de medio cesto de sardiñas, dejando atónitos a los circunstantes ${ }^{6}$. Desde Pontevedra, por fin, Estebanillo se traslada a Salvatierra, y cabe asegurar que tenía interés especial en visitar la villa puesto que si, como parece, su intención era ya la de penetrar en Portugal, tuvo que desviarse algo de su camino más recto.

El reencuentro con el solar de los González le sirve para reiterar, más de

cia de infamia a nativitate en el Estebanillo González. En realidad, ello me parece evidente y, hasta donde sé, nadie ha afirmado, en fecha próxima, lo contrario, si se hace abstracción del prólogo y algunas notas de la desafortunada edición de N. Spadaccini y A. Zahareas (Madrid, 1978). Por otra parte, es el propio autor de La vida y hechos quien incurre en ciertas concesiones al topos picaresco de la denigración de los progenitores, sea ello o no simple recurso bufonesco. Recuérdese, símplemente: Murió mi madre de cierto antojo de hongos, estando preñada de mi padre, "según ella decía" (I, 39), y el resto del pasaje.

${ }^{6}$ Según indicamos en nota a nuestra ed. (IV.37), el sardiñas del texto es un galleguismo deliberado que aparece sólo en la primera edición de Amberes y deja de imprimirse a partir de la edición madrileña, segunda, de 1652. La caracterización de Pontevedra coincide con la que siglo y medio antes hacía Hieronymus Münzer: Caminamos las tres leguas que hay desde Redondela a Pontevedra, ciudad antiquísima y no grande, pero con buen puerto de mar y mucha pesca de sardina, principal alimento de toda aquella comarca, Itinerarium sive peregrinatio per Hispaniam... (1494). El texto latino manuscrito fue descrito y estudiado por L. Pfandl, Beiträge zur spanischen und provenzalischen Literatur -und Kulturgeschichte des Mittelalters (Bayreuth: L. Ellwanger, 1915), 33-58, y editado por el mismo Pfandl en la Revue Hispanique, XLVIII (1920), 1-178; la traducción española es la de J. Puyol, BRAH, LXXXIV (1924), p. 218.

"CUADERNOS DE eSTUdIOS GALLEGOS", Tomo XL, Fascículo 105, Santiago 1992. 
pasada y ya sin especiales sarcasmos, sus dudas acerca de su lugar de nacimiento, a la par que recuerda un nuevo dicho infamante o simple matra$c a$ contra los gallegos, que esta vez se pone en boca ajena a la del narrador. Fueran las que fuesen las reticencias de Estebanillo a aceptar a Salvatierra como patria, no hay duda de que esa era la villa natal de sus padres. El pícaro sacará buen partido de ello y relata un embuste, de tono menor en esta ocasión, que le permite vivir algunos días a costa de un pariente:

Pasé de allí a Salvatierra, solar esclarecido de los Muñatones y patria de mis padres, que no oso decir que es mía por lo que he referido de mi nacimiento, y porque todos mis amigos, llegando a adelgazar este punto, me dicen: antes puto que gallego. Informéme del nombre de un tío mío, y en creencia de una carta que fingí de mi padre, contrahaciendo su firma, fui ocho días regalado dél, y a la desp[ed]ida me dio cincuenta reales y respuesta de la carta, por haberle asegurado que me volvía a Roma (I,177).

Las demás alusiones que el protagonista hace a sus orígenes no siempre implican necesariamente una sátira simultánea contra Galicia y los gallegos. Es todavía ambivalente una referencia del capítulo II: al volver de la expedición naval contra los turcos, en 1621, un gentilhombre, secretario de la hija de D. Juan de Austria, le ofrece tomarlo por criado; y Estebanillo se apresura a aceptar:

Díjele que le serviría con mucho gusto; y dándole el nombre como a soldado que está de centinela, y negándole el tener padre ni ser medio romano, me vendí por gallego, y se echó muy bien de ver que lo era en la coz que le dí y en la que le quise dar (I,97-98).

El hacerse pasar por enteramente gallego parece ser, pues, una buena carta de presentación, pero la coz galiciana que completa el se echó muy bien de ver que lo era (es decir, que era gallego), nos devuelve al plano de la autodenigración ${ }^{7}$. El criado muestra pronto, en efecto, ser poco de fiar: roba a su amo y se descuida en atender sus obligaciones. El insulto que recibe

${ }^{7}$ Cf. p. 217 y nota II.137, con la explicación que daba el Dr. L. Galindo, hacia 1660, sobre el dicho dar coz como gallego aplicado a los servidores de la plebe galiciana.

"CUADERNOS DE ESTUDIOS GALLEGOS", Tomo XL, Fascículo 105, Santiago 1992. 
de su patrón era fácilmente predecible:

- Pícaro gallego, ¿es menester que ande yo siempre tras vos diciéndoos lo que habéis de hacer? Como tenéis habilidad para comer, ¿por qué no la tenéis para servir, teniendo cuenta, pues no sois de los que buscaba Herodes, de lo que yo necesito, para hacerlo sin que yo os lo mande? (I,97-98).

Similar ambivalencia se produce en otro episodio de la biografía de Estebanillo, algunos años después, en una de las varias ocasiones en que ejerce el oficio de soldado. En 1632 es sentenciado a la horca en Barcelona, acusado de desertor y alborotador de la armada. Para diferir la ejecución de la sentencia esgrime su calidad de hidalgo y solicita el privilegio de ser degollado. Claro es que en su presunto deseo de obtener una muerte más noble no existe la menor preocupación real por los puntos de honra, y el propio pícaro confiesa paladinamente que su único propósito era hacer posible la fuga mientras se hacía información sobre su hidalguía en Roma y Salvatierra:

Hice dar un memorial en mi nombre al Marqués de Este [...], alegando en él ser hijo de algo, y que, conforme los fueros de los que eran, me tocaba morir en cadahalso degollado como carnero, y no en horca ahogado como pollo. Pensaba que me pediría información dello y que me daría término para enviar a hacer las pruebas a Roma y a Salvatierra, y que en el ínter no me faltaría una lima sorda para limar la cadena y grillos o una ganzúa para abrir las puertas de la prisión; pero salióme todo vano, porque el Marqués respondió que él no pretendía otra cosa sino que yo muriese ajusticiado, que en lo demás escogiera yo la muerte que quisiera $(I, 275)$.

En el mismo episodio, y en idéntico registro humorístico, Estebanillo pide luego a unos mediadores un nuevo favor:

Que si sus mercedes pudieran alcanzar con mi general que, debajo de mi palabra, me diese licencia por tres meses para ir a Roma a confesar ciertos pecados reservados a su Santidad, para descargo de mi conciencia y salvación de mi alma, me haría muy grandísima merced y favor; y que yo les haría pleito homenaje, como infanzón gallego, de 
volver, en cumpliéndose el término, a ofrecerme al funesto suplicio y a entregar al trinchante de gargueros la mejor cabeza que jamás ciñó garzota $(\mathrm{I}, 277)$.

De "hidalgo" hemos ascendido a "infanzón", y el jurar como gallego está aquí para reforzar-si alguna duda hubiese- que Estebanillo no tenía la menor intención de cumplir su palabra de regresar para ser ejecutado, en el improbable caso de que se le otorgara la merced. Seguiríamos, pues, dentro de un mundo referencial que hace de Galicia y lo gallego un cómodo expediente para denotar una realidad negativa, aunque haya desaparecido la violencia en el desprecio de las primeras páginas. Queda claro también, al menos, que la hidalguía y el infanzonazgo no son incompatibles con la nación (en el sentido del s. XVII) gallega, a pesar de la negatividad inherente a esa procedencia. Lo mismo sucedía ya cuando, como hemos visto, en su visita a Santiago se excusaba de alabar la belleza y grandiosidad de la villa, por que no me tengan por parte apasionada, por lo que tengo de gallego.

En cambio, es ya del todo neutra, mera constatación de hechos sin ironía alguna, la alusión lingüística que sirve para justificar la casi excesiva facilidad con que Estebanillo engaña a los mercaderes portugueses, y judíos, de Rouen:

Me fui a la Bolsa, que es la parte del contratamiento y junta de todos los asentistas y hombres de negocios. Yhallando un agregamiento de mercaderes portugueses, metiéndome en su corro, y no a escupir en rueda sino a hacellos escupir en corrillo, les hablé con la cortesía y sumisión que suele tener el que ha menester a otro, y en su misma lengua por que no escusasen la súplica, porque como mis padres se habían criado en la raya de Portugal la sabían muy bien y me la habían enseñado; $y$, después, de haberles dado a entender ser lusitano, les pedí que me amparasen para ayuda a poder llegar a la ciudad de Viena $(\mathrm{I}, 248)$.

Neutras también, e incluso positivas, son las referencias a la galleguidad del personaje que se hallan en la segunda mitad de la autobiografía. En su camino de Viena a Milán, en 1644, Estebanillo viaja en compañía de un capitán genízaro, que revela ser tan avaro como orgulloso, y que en algún momento pretende avasallar al pícaro. Finalmente, 
Llegamos a Chavena, adonde me embarqué yo y mis caballos y mis criados, y en vanguardia el capitán, mi señor; el cual, como me vio que iba algo rostituerto, y él se halló en tierra del Rey de España, me empezó a echar rodamontadas, como si fuera estraña para mí siendo medio gallego, y patria para él siendo medio alemán (II,245).

La calidad de medio gallego le sirve ya para estar en pie de igualdad en cuanto al honor de ser súbdito del rey, con el rodamontado capitán. También ese rótulo de gallego a medias es esgrimido por el pícaro en un arrebato rufianesco con una cortesana de Nápoles; el ser medio galle go sirve, fictivamente, como tarjeta de visita para infundir temor a otros, aunque Estebanillo tardará poco en arrepentirse de su bravata:

Alcé la mano y dile un par de tamboriladas que no se las dio mejores el obispo que la confirmó, y haciendo de el rufián le dije:

- Dile a tus bravos que me las vengan a pedir, que Estebanillo Gonzales me llamo por mar y por tierra, medio gallego y medio romano (II,271-272).

Por último, el protagonista decide olvidar todas las reservas sobre su lugar de nacimiento, e incluso manifestará orgullo -se diría- por ser hijo de Salvatierra. Cierto que en la aceptación final de su patria gallega y de la villa del Miño -el rabo de Castilla y albañal de Portugal de las primeras páginascomo lugar natal tiene lugar sólo como la necesaria vía para reconocerse antiguo y fiel vasallo de un Felipe IV al que debía especiales favores:

Yo quedé tan ufano y tan agradecido de ver que un refulgente Apolo y un león coronado se acordase de remunerar servicios tan inútiles y hechos por tan humilde sabandija, que, a no saber que mi madre me había parido en Salvatierra de Galicia, reino que me ha honrado en poderme nombrar su leal vasallo, me hubiera, al mismo punto que recebí la merced, partido por la posta a Roma y sacado su esqueleto de la tumba adonde yace; y trayéndolo lleno de paja, como caimán indiano, en llegando con él al primer puerto de cualquiera de sus reinos, lo vaciara y me zampara de nuevo en su vientre, aunque estuviera en él en cluquillas, y la obligara a que me volviera a parir vasallo de tal deidad (II,334). 
El ser gallego, a fin de cuentas, ha servido al pícaro para garantizarse su ascenso final en la peculiar carrera de oficios y honores iniciada con su primera salida de Roma. Las declaraciones en que Estebanillo gustaba de presentarse como apátrida han cedido a la hora de solicitar y obtener mercedes tangibles. Igualmente inútil era a esos efectos la calidad de ciudadano de la cabeza del mundo o cabeza de la Cristiandad, la Roma que decía haber tenido siempre en lugar de patria (II,259). Roma no podía conferir el estatuto de súbdito de la Monarquía hispánica, y a la hora de la verdad el gallego-romano Estebanillo silencia el segundo y se atiende sólo al primero de los términos de la fórmula que había acuñado para autodefinirse. El origen gallego le proporciona la única vía posible de integración social, de disfrute en las migajas de la mesa de los poderosos, y el logro final de sus aspiraciones sedentarias, cifradas en regentar un garito en Nápoles, es decir en uno de los territorios más prósperos de la Monarquía, con la autorización y el refrendo del Felipe IV, del Consejo de Italia y del virrey.

A partir de aquí se entiende que a Estebanillo se le olvide el ser medio romano. En la última alusión a sus orígenes que aparece en el libro, el bufón deja constancia de cuál sería la procedencia nacional que figuraría en su epitafio:

A una legua de Tafalla, emparejando con una ermita que está cerca del camino real, ni sé si por hacerle reverencia, si por ir lleno de sueño o por caminar cargado de vino, di una caída de la mula abajo tan feliz y venturosa que, sin romperme la manga de la hungarina polaca ni la del jubón napolitano ni la de la camisa española, me hice pedazos un brazo, por ser la mula pequeña de cuerpo y el camino llano y arenoso. Quedé el hombre más contento deste mundo de ver que mi caída no necesitaba la insignia; porque más gusto que en cualquier tiempo digan lo que vieren el revolcadero: aquí cayó un lobo gallego, que no: aquí mataron a un hombre; rueguen a Dios por él. (II,339).

Al final de la pseudo-autobiografía de Esteban González se ha dado la vuelta a la aparente infamia original. La denigración de Galicia se revela como un simple cliché literario, un recurso bufonesco manejado de acuerdo con la personalidad del biografiado, que le permitiría hacer fáciles humoradas a su propia costa. En tal sentido, sucede algo muy similar con otro de los lugares comunes consagrados en la literatura del barroco español, es decir la constante sátira sobre la hidalguía no acompañada de bienes de fortuna, 
sátira que en el Estebanillo González aparece puesta en boca de quien ha empezado por declararse hidalgo. En párrafo varias veces recordado:

Mi padre [...] tenía una desdicha que nos alcanzó a todos sus hijos, como herencia del pecado original, que fue ser hijodalgo, que es lo mismo que ser poeta; pues son pocos los que se escapan de una pobreza eterna o de una hambre perdurable. Tenía una ejecutoria tan antigua que ni él la acertaba a leer, ni nadie se atrevía a tocarla, por no engrasarse en la espesura de sus desfloradas cintas y arrugados pergaminos, ni los ratones a roerla, por no morir rabiando de achaque de esterilidad (I,38-39).

No creo, pues, que la galleguidad de Esteban González, en cuanto personaje literario, sea el sustituto funcional de la prehistoria familiar infamante, la fuente de todo deshonor, que ponía en marcha las biografías de los pícaros canónicos (Lázaro, Guzmán, Pablos). La calidad social y moral de los progenitores de Guzmanillo o don Pablos son datos inmutables, además de personales e intrasferibles; al pícaro sólo le cabe tratar de ocultarlos en donde no le conozcan y asumir, como impostor, otras posibles identidades. El hecho, en cambio, de ser originario de una zona rústica y poco civilizada como Galicia, según se daba por supuesto en la época, no dejaba de ser una seña de identidad colectiva, que incluía a todo un conde de Gondomar o al conde de Lemos, por no salirnos del siglo XVII. Las matracas y dichos denigratorios que los demás prodigaban contra Galicia podían ser asumidas con buen humor por los propios gallegos, y el mismo Gondomar de buen ejemplo de ello. Bastará que se produzca el ascenso a la cumbre de su buena fortuna para que el pícaro-hidalgo Esteban González se sienta retrospectivamente satisfecho y honrado por su nacimiento en Salvatierra de Miño.

\section{Un pintor gallego en Roma. Salvatierra en el s. XVII}

Las primeras precisiones que se hacen en La vida y hechos de Estebanillo González sobre el protagonista, esto es el ser hijo de un pintor nacido en Salvatierra y establecido en Roma a principios de siglo, tienen -según hemos expuesto en otro lugar y extractaremos aquí- plena confirmación documental. Los registros de la Academia romana de San Lucas, organización gremial de los pintores de la corte pontificia, revelan la presencia entre sus 
miembros de un Lorenzo Gonzales, pitore spagniolo, de 1604 a 1626, que es indudablemente el padre del gallego enjerto en romano que dice ser Estebanillo.

Las referencias que nos interesa aquí consignar son las siguientes:

A di' 8 di Luglio 1604

E a di' detto, ricevuto da rincontro miser Lorenzo Gonzales, pitore spagniolo, p. 50, li quali pagato a bon conto p. suo introito, sí come apare a libro de l'entrate al arte, $21 . . .50$.

A di' 25 di Luglio 1604

E a di' detto, ricevuto dal su dito Lorenzo Gonzales p. 20, a bon conto p. suo introito, sí come apare a libro de l'entrate al arte, $22 . . .20$.

A di' 31 di Genaro [1605]

E a di' detto, recevuto io, Domenico Contielli, camarlengo, scudi uno, per da m. Lorenzo Gonzales sudetto, quali sono per resto del suo introito, sí come apare ne' libro de l'entrate al arte, 27....20 ${ }^{8}$.

Varias otras anotaciones en 1604 y 1605 insisten en la apostilla pitore spagniolo o spagniolo, que desaparecen del todo en 1607, año en que el nombre se italianiza en Laurenzo Gonzales. El registro Congregationes universitatis pictorum, ab anno 1618 usque 1622, o elenco de juntas de la Academia, anota nuevas menciones de Lorenzo González, como asistente, en diciembre de 1618 y enero-marzo de 1619. Desde 1618 se le da el título de signore; en 1625 fue elegido camarlengo de la Academia, y como tal firma en el libro registro de cuentas, Entrate e uscite del Camarlengo, 15931625. Continuaba ejerciendo ese cargo el 18 de octubre de 1626, fecha a que corresponde la última mención de Lorenzo González en la documentación extractada por Martínez de la Peña.

Aunque debe tenerse en cuenta que la documentación de la Academia de

\footnotetext{
${ }^{8}$ Libro antico degl' accademici ed aggregati, 1535-1653, transcripción de D. Martínez de la Peña en Artistas españoles en la Academia de San Lucas (Documentos de los siglos XVI y XVII), Archivo Esp. de Arte, XLI (1968), nº 164, s.p.
}

"CUADERNOS DE ESTUDIOS GALLEGOS", Tomo XL, Fascículo 105, Santiago 1992. 
San Lucas de Roma se conserva sólo de forma incompleta, en lo conservado hay ya datos de suficiente interés que nos interesa confrontar con los del Estebanillo González.

De acuerdo con las fuentes de archivo, el pintor Lorenzo González llegó a aclimatarse social y profesionalmente en su etapa romana hasta el extremo de naturalizarse y dejar de mencionarse desde muy pronto su origen español; todo indica que era hombre respetado dentro de su gremio profesional, en el que llegó a alcanzar un puesto de responsabilidad. Ello está en consonancia con la caracterización que Estebanillo hace de su padre, a quien no se presenta en modo alguno con unos rasgos que se ajusten al topos del padre del pícaro. Según la Vida y hechos, el padre del protagonista se preocupa de dar estudios a su hijo, y, al ser expulsado de la escuela por sus travesuras, lo acomodará dos veces como aprendiz de un oficio, ofreciendo fianzas que finalmente habrá de pagar. El pintor era hombre muy severo, bien relacionado con el embajador español en Roma, y había alcanzado un cierto desahogo económico: al morir legará a su hijo una casa en la calle Ferratina, entre otros bienes que Estebanillo se apresura a malvender en Palermo, y los que se supone que dejaría a las dos hermanas del protagonista, y a las que éste aspiró también en heredad. No se ve en ninguna parte de la obra que Estebanillo manifieste especial desvío o animosidad contra la figura paterna, por más que la autocaracterización negativa del personaje arrastre la de los demás tipos humanos que aparecen en la obra, con la excepción del mundo intangible de la nobleza y las glorias militares. Hay mucho de esperpéntico en las primeras páginas que describen el ámbito familiar, con evidentes deudas a modelos literarios preexistentes. Pero las ironías sobre los pruritos linajudos del pintor, que guardaba celosamente su ejecutoria del hidalgo, o las alusiones a que fuese jugador de naipes, no implican en sí mismas nada de inverosímil ni denigratorio. Baste recordar, sobre lo segundo, las pérdidas en el juego de otro pintor mucho más célebre, el Greco, que fue también miembro de la Academia de San Lucas; y, respecto al énfasis en la hidalguía, no hay en el Estebanillo simple parodia literaria si se atiende a que dentro de la perspectiva del s. XVII español la posibilidad de hidalguía en los pintores fue objeto de discusión, dado que ejercían un oficio mecánico, por mucho que el arte lo dignificara. En una comedia coetánea al pasaje del Estebanillo, Lope de Vega, creyó todavía conveniente afirmar la compatibilidad de la hidalguía con la profesión de pintor:

Y que puede con decencia cualquier hidalgo ejercer 
(si a las historias creemos,

o a la verdad, si debemos

más a la verdad creer)

el oficio de su padre

digo el arte de pintor. ${ }^{9}$

Ignoramos las cualificaciones de Lorenzo González como artista. En una primera indagación sobre la pintura en Roma en el primer cuarto del siglo XVII no hemos hallado ninguna referencia a su persona ni a cuadros conservados actualmente que lleven su firma ${ }^{10}$. Es posible que fuesen obra de su padre todas o gran parte de la gran suma de pinturas que Estebanillo obtiene a cambio de la casa que había heredado y que enajena poco después en Nápoles, llegando a jugarse, y perder, cincuenta cuadros en una noche.

Hasta aquí lo que afirmábamos en 1989 en un estudio dedicado a La personalidad real de Stefaniglio. Para deducir, con plena seguridad a nuestro juicio, que Lorenzo Gonzálezes, efectivamente, el padre del protagonista de la biografía picaresca publicada en 1646, bastaría la identidad de apellido y el cotejo de la cronología que se establece en los registros de la Academia romana con la del Estebanillo González. No abundan, ciertamente, los pintores españoles que trabajaban en Roma en esos años, e imaginar otro Gonzales -forma en la que Estebanillo escribe también su apellido en alguna ocasión- pintor español en Roma y distinto del emigrado de Salvatierra supondría una más que inverosímil casualidad.

La seguramente innecesaria confirmación de la exacta historicidad del Estebanillo González en este punto, puedo proporcionarla ahora, tras haber examinado la escasa documentación parroquial que sobrevive de la Salvatierra de Miño del siglo XVII.

En una primera visita, en 1971, tuve conocimiento de que no se conservaba en Salvatierra ninguna documentación eclesiástica anterior a 1660. Durante la ocupación portuguesa de la villa, entre 1643 y 1659, los

\footnotetext{
${ }^{9}$ Los Ponces de Barcelona (c. 1610), I, ed. N. Ac., VIII, p. 572.

${ }^{10} \mathrm{Cf}$., por ejemplo, G. Baglione, Le vite de' pittori [...] del pontificato di Gregorio XIII, del 1572 infino a' tempi de Papa Urbano VIII nel 1642 (Roma 1642). La obra era, acaso, la más indicada para proporcionar algún dato sobre Lorenzo González, si este hubiera tenido algún relieve como pintor, dado que se ocupa de artistas que trabajaron en Roma, incluyendo a los extranjeros y a varios que son hoy del todo desconocidos, con la única condición de que hubieran muerto antes de 1642.
} 
libros de la parroquia habrían sido trasladados a Monçao y no fueron ya recuperados. No tuve la oportunidad de verificar estos informes hasta el pasado verano de 1989 , con motivo de los trabajos preparatorios para la nueva edición. En principio, una vez que Monçao fue, a su vez, ocupado por los españoles en 1659, al mismo tiempo que se recuperaba Salvatierra, parecía lógico suponer que una documentación (libros de bautismos, matrimonios y defunciones) que siempre se ha considerado importante en la vida de cualquier comunidad, habría sido devuelta en el caso de que en efecto se hubiera hallado en Monçao. Los informes que obtuve en la ciudad portuguesa fueron del todo negativos: no se conserva en la Câmara municipal de Monçao papel ninguno procedente de Salvatierra, según testimonio de D. Joaquin Magalhaes, presidente de la Câmara, que amablemente atendió a mis consultas. Es más: la destrucción de los propios registros municipales de Monçao anteriores al s. XVII se achacaba a los daños del asedio y posterior ocupación española de esta ciudad fronteriza, entre 1659 y la paz de Lisboa de $1668{ }^{11}$. La documentación parroquial de Monçao, en cambio, no parece haber sufrido pérdidas y se encuentra hoy transferida al Arquivo distrital de Viana de Castelo, donde se contabiliza un total de trece libros de nacimientos, bodas y defunciones, con registros fechados de 1534 en adelante. Los inventarios generales de este archivo, el de Alto Minho, no revelan tampoco la existencia de ningún libro parroquial perteneciente a Salvatierra ${ }^{12}$. En consecuencia, no parece que sea posible verificar ya si la documentación eclesiástica de Salvatierra estuvo o no en Monçao, aunque sí es cierto, como

\footnotetext{
${ }^{11} \mathrm{~J}$. Garçao Gomes, Para a pequena história de Monçao. Das actividades municipais e da governança durante a ocupaçao espanhola, Arquivo do Alto Minho, XXVII (1982), págs. 48-108. En párragos no exentos de retórica hispánica, Garçao Gomes alude también, al margen de los desastres producidos por el asedio y los malvados invasores, a la incuria de las sucesivas administraciones municipales: Todos esses documentos que seriam riqueza e orgulho do seu minicípio, todos desapareceram devastados pelas operaçoes de guerra, destruidos selváticamente pela soldadesca invasora, arruinados pelo desmazelo e ignorância de muitas vereaçoes, dispersos por arquivos de outros concelhos em tentativas, quiçá inoperantes, de os preservar (p. 49). Peor aún fue la suerte de la documentación civil de Salvatierra, desaparecida por completo en un incendio de 1914 (informe del secretario del ayuntamiento, D. P. Suárez).

${ }^{12}$ Cf. M. Gonçalves Vale, Inventário geral en Estudios Regionais, Revista de Cultura do Alto Minho, 5, 1989, págs. 111-125. Dado que Gonçalves Vale aludía a fondos aún no inventariados, realicé en 1991 una visita al Arquivo de Viana do Castelo, en donde se me confirmó la inexistencia de libros parroquiales que procediesen de Salvatierra.
}

"CUADERNOS DE ESTUDIOS GALLEGOS", Tomo XL, Fascículo 105, Santiago 1992. 
veremos, que su desaparición a la ocupación portuguesa de 1643.

Tras estas comprobaciones negativas en Salvatierra y en Portugal, sólo cabía examinar la documentación de la villa pontevedresa que subsiste, posterior a 1660, con la esperanza de que -a pesar del más de medio siglo transcurrido desde el año presumible del nacimiento de Estebanillo Gonzálezarrojase alguna luz sobre la Salvatierra seiscentista que pudiera sernos útil. Los libros parroquiales, conservados hoy en el archivo diocesano de Tuy, incluyen, entre otros, un registro de bautismos de 1662-1724 y las actas de una cofradía local, de 1661-1770. Este último, junto a varias noticias de interés, nos informa de que los libros desta santa cofradía los robó el rebelde cuando se apoderó desta villa, y que al rebelde portugués se debió también el robo de la imagen del santo patrono de la iglesia y feligresía. Del libro se deduce también que los moradores de Salvatierra hubieron de abandonar la villa y vivir fuera de ella mientras permaneció en manos portuguesas, hasta que las católicas armas de su Majestad el reydon Felipe quarto, nuestro señor, la recuperación del poder y tiranía del rebelde portugués.

Dada la imposibilidad, con la documentación disponible, de explorar los antecedentes familiares directos del Esteban González histórico, he dirigido mi atención a los datos que podían extraerse de la onomástica personal, es decir un aspecto en la vida de los pueblos cuya relativa fijeza, incluso en largos periodos de tiempo, es bien conocida. Como punto de partida he tomado los nombres y apellidos que figuran en el registro de bautismos, en calidad de padres o padrinos, entre 1662 y 1672, y los que se consignan en el libro de la cofradía como fundadores y donantes. En total, eliminando las repeticiones de un mismo individuo, pueden evaluarse en cerca de unos dos centenares los nombres de vecinos de Salvatierra y aldeas aledañas que aparecen en esta documentación. No siempre puede decidirse, en el caso de nombres y apellidos que se repiten, si se trata de una misma o distinta persona; el margen de seguridad es mayor cuando consta el nombre del cónyuge, lo que permite descartar posibles homónimos; ese apoyo no existe cuando los inscritos figuran en calidad de padrinos, y sólo ocasionales referencias a la aldea precisa donde estaban avecindados puede ayudarnos a distinguir personas con los mismos nombres y apellidos y a descartar a los ya registrados. Excluyo también los nombres de personas en los que los registros hacen constar expresamente que se trataba de soldados y oficiales de la guarnición del castillo; entre ellos se incluyen a varios portugueses, andaluces y hasta flamencos, cuya onomástica contrasta vivamente, claro está, con la de 
los nativos en la villa de Salvatierra y su feligresía. Con las salvedades de posibles errores en la identificación de homónimos, y sin tener en cuenta algunos nombres que me han resultado indescifrables, por mal estado del original o por utilizarse abreviaturas cuya resolución no era del todo evidente, he despojado sistemáticamente todos los antropónimos que figuran en la documentación manejada dentro de los términos cronológicos indicados.

Creo que las personas mencionadas en estos libros parroquiales representan una parte muy elevada del censo total de habitantes en la década de 16611670 , sobre todo teniendo en cuenta que el núcleo de Salvatierra no parece haber sido nunca muy grande. Según Gándara era Salvatierra un lugar de 200 casas, de las que la mitad constituían un arrabal que fue enteramente destruido en 164[3] por los ocupantes portugueses ${ }^{13}$. Hasta tiempos muy recientes la villa no alcanzó el millar de habitantes. Para el conjunto de la parroquia daba Miñano en 1827 unas cifras de 258 vecinos y 1.156 habitantes, que Madoz, en 1849, reduce a 203 vecinos y 812 almas; pero la villa propiamente dicha no llegaba, todavía en el censo de 1910, a una centena de moradores. En las fechas que aquí nos ocupan debe además tenerse en cuenta que la población de Salvatierra había sido expulsada por la guarnición portuguesa que ocupó la villa y Castillo; y es evidente que no todos sus antiguos habitantes regresaron, al restaurarse Salvatierra dieciséis años después. Los que volvieron tenían clara conciencia de estar refundando una villa que había quedado considerablemente mermada respecto a los tiempos anteriores a la invasión. El informe coetáneo de fray Cristóbal de Peralta señalaba, en 1659, que el sitio de Salvatierra no es inferior al de Monzón, pero la guerra tiene tan destruido el uno como el otro ${ }^{14}$. El descenso de población hubo de

${ }^{13}$ Fr. Felipe de la Gándara, Armas y triunfos. Hechos heroicos de los hijos de Galicia, (Madrid, 1662), p. 644.

${ }^{14}$ La relación de este fraile cisterciense, del monasterio de San Clodio de Ribadavia, fue transcrita por J. B. Mahn, Une relation inèdite de la prise de Monçao (1659), Hispania, III (1943), pp. 431-438. Mahn completa la relación del monje con algunos datos extraídos de dos impresos que forman parte de la célebre Colección Mascareñas, hoy en la Biblioteca Nacional de Madrid (Mss. 3.387, núms. 5 y 6). El relato más detallado de la torna de Monçao y Salvatierra es, sin embargo, el que incluye Gándara en Armas y triunfos... de los hijos de Galicia, capítulos XXXI-XXXIII. Estas operaciones militares, de las más importantes, y unas de las pocas afortunadas para las armas de Felipe IV, en toda la larga guerra hispano-portuguesa, no son ni siquiera mencionadas en la monografía clásica de Estébanez Calderón, De la conquista y pérdida de Portugal (Madrid, 1885), que dirige su atención casi exclusivamente al frente de Extremadura. Gándara tenía buenas razones para contrastar, en el mismo año 1659, el éxito del ejército del Norte, compuesto por

"CUADERNOS DE eSTUdIOS GALLEGOS", Tomo XL, Fascículo 105, Santiago 1992. 
afectar también en alguna medida a las aldeas de la feligresía de Salvatierra que aparecen repetidamente mencionadas en la documentación que manejamos: Freixendo, Casal, Outeiriño y Os Ramallás. Estas aldeas formaban un todo con la villa en cuanto se refiere a inscripciones en los registros de bautismos y en los de la cofradía.

A efectos de la onomástica personal, el primer dato que interesa consignar es la advocación del santo patrono de la villa, iglesia y feligresía de Salvatierra. Este santo y único patrón no es otro que San Lorenzo; la villa y sus aldeas integraban la parroquia de San Lorenzo de Salvatierra y ese es el nombre con que fue conocida hasta fines del s. XIX, puesto que Salvatierra de Miño es denominación no tradicional e impuesta sólo en tiempos muy recientes; también, la cofradía a que ya hemos aludido no tenía otra finalidad que rendir culto y exaltar al diácomo mártir, con celebraciones especiales en el día de su fiesta. Esa advocación del patrón de la villa, se traduce, como es lógico y ha seguido siéndolo hasta mucho tiempo después en toda España, en la frecuencia con que el nombre del santo se repite en los nombres de los vecinos de la parroquia. En el caso de Salvatierra, en efecto, Lorenzo es el nombre de pila más abundante entre los varones. Hasta veintidós personas distintas aparecen en el registro parroquial con ese nombre, y su abundancia en términos relativos y absolutos podrá apreciarse mejor en el cuadro completo de antropónimos: Alonso (2); Alvaro (2); Andrés (1); Antonio (4); Benito (1); Diego (1); Domingo, o, en la forma que predomina, Domingos (8); Fernando (4); Francisco (2); Giraldo (1); Gómez (1); Gregorio (5); Jacinto (1); Jácome (1); Juan (16); Lorenzo (22); Mateus (1); Melchor (1); Pedro (10); Salvador (2); Simón (1). Súmese a ello el uso de Lorenzo como apellido: hay cinco personas distintas nombradas Juan Lorenzo, un Domingos Lorenzo, y hallamos también, adaptado al femenino, dos María Lorenza y una Miguela Lorenza.

Si pasamos a los patronímicos, el examen del libro de bautismos y el de la cofradía de San Lorenzo no deja lugar a dudas: González, o Gonzales, era, con mucho, el apellido más frecuente entre los moradores de Salvatierra y las aldeas de su feligresía en los años de 1660-1670. Más de treinta personas llevan ese apellido, seguido de lejos por otros de los que hoy consideramos

milicias gallegas sostenidas por el propio reino, con el fracaso del ejército castellano ante Elvas, con D. Luis de Haro en persona y los generales más prestigiosos de la maltrecha Monarquía. 
más comunes: Pérez, o Peres (10), López (8), Alvarez (7), Vázquez (7), Fernández (6), Martínez (4), Domínguez (1), Sánchez (1), Suárez (1); junto a ellos, otros que no son derivados de nombres propios, ofrecen cifras que tampoco son comparables al apellido que aquí nos interesa: Araujo (3), de Barros (3), Blanco (1), de Camba (1), de Castro (2), do Campo (1), Cuña o Acuña (3), de Figueiral (1), da Fonte (1), de Fontaiña (3), de Granda (1), de Guillade (1), da Iglesia (4), de Lagares (1), de Montes (4), Mouriño (1), Ogea, o Ougea (7), Pereira (2), da Porta (1), do Porto (1), Puga (2), Rabal (1), Regueira (1), Requexo (4), Sa o Saa (3), Sarmiento (1), Soto o Souto (4), de Tapia (1), de Torres (1), Vaquero (4), Vaz (3), Vidal (1).

La relativa abundancia del apellido López podría prestar más verosimilitud de la que era previsible a un episodio en el que Estebanillo informa del nombre completo de su madre. Lo cierto es que se trata de un episodio notoriamente burlesco y del que se han señalado precedentes literarios bien conocidos. En la batalla de Nördlingen, después de haber estado indeciso el resultado, el pícaro advierte que los españoles e imperiales llevaban la mejor parte:

Y, dando un millón de voces a pie quedo, empecé a decir:

-¡Santiago, Santiago! ¡Cierra, España! ¡A ellos, a ellos! ¡Cierra, cierra!.

Y presumo que acobardado el enemigo de oírme o atemorizado de verme comenzó a desmayar y a poner pies en polvorosa. Empezó todo nuestro campo a apellidar: ;Vitoria, vitoria!.

Yo, que no me había hallado en otra como la presente, imaginando que llamaban a mi madre, que se llamaba Vitoria López, pensando que estaba conmigo y que la había traído en aquella jornada, les respondí al tenor de las mismas voces que ellos daban que dejasen descansar los difuntos, y que si alguno la había menester que la fuese a buscar al otro mundo (I,314).

El autor nos tiene acostumbrados a bufonadas similares, pero la apoyatura del chiste puede estar muy bien basada en el nombre y apellido real de la madre del protagonista, por más que la ocurrencia proceda acaso de un pasaje, no menos inverosímil, del Buscón (I,2) de Quevedo.

Volviendo a Salvatierra, la combinación del nombre y el apellido más frecuentes da lugar a que existan unos diez homónimos absolutos del pintor establecido en Roma a principios de siglo. En la villa hallamos un Lorenzo González, casado con María Lorenza (registrado el 20-XI-1662), otro, marido de Catalina Vázquez (12-I-1663), y otro mas, muy posiblemente

"CUADERNOS DE ESTUdIOS GALLEGOS", Tomo XL, Fascículo 105, Santiago 1992. 
distinto de los anteriores, que figura como padrino junto con María González (29-V-1663); en Outeiriño aparece otro Lorenzo González marido de Inés Vaquero (21-XI-1663 y 23-XI-1664); en Casal aparecen otros dos seguros, casados respectivamente con María González (29-IX-1664) y María López (6-III-1665), y un tercero probable que figuraba como padrino junto María Rabal (29-IX-1672); de Freixendo era otro Lorenzo González, padrino junto con Ana Sánchez (20-XII-1661); y en Os Ramallás se registran un Lorenzo González, hijo de Juan González y María de Requexo (16-III-1663), y otro, sin duda distinto, que se inscribía como padrino (21-III-1663).

Tras estas comprobaciones onomásticas, ciertamente poco amenas, creo que puede darse por seguro que Estebanillo y el autor del libro impreso en Amberes, que se permitieron tantas elaboraciones puramente literarias ( $y$, en varias ocasiones, muy afortunadas) al trazar la biografía picaresca del gallego-romano, no falsearon la realidad en lo que respecta a sus orígenes. Cierto que la historia literaria dista mucho de ser una ciencia exacta, pero incluso en puntos tan secundarios como el que aquí nos ha ocupado pueden hallarse acumulaciones de datos coincidentes, que equivalen a la evidencia. En la Vida y hechos de Estebanillo González se afirmaba, entre ironías y convenientemente relativizado al principio, el nacimiento del protagonista en Salvatierra de Galicia, pero que ése era el solar de sus padres es algo dicho con entera seriedad. Ahora bien el nombre del padre es omitido en la autobiografía picaresca del siglo XVII, y sólo en el XX lo ha desvelado un historiador del arte al investigar la presencia de pintores españoles en la corte romana, con propósitos muy distintos de los nuestros, en registros que identifican a Lorenzo González como spagniolo a secas. Por último, los documentos parroquiales que se han salvado muestran que, en efecto, el pintor, emigrado por oscuras razones que difícilmente podrán saberse, tiene todas las probabilidades de haber salido de la villa donde los Lorenzo y los González seguían siendo mayoría sesenta años depués.

En cuanto a la presunta hidalguía de su padre, tendremos que seguir creyendo a Estebanillo bajo su palabra. Son, al menos, contados los vecinos de Salvatierra que ostentaban el título de Don, y entre ellos ninguno llevaba el apellido González. Claro está que el dato no es decisivo, pero no deja de ser un indicio ${ }^{15}$.

${ }^{15}$ Sobre la hidalguía del autor contrapuesta a la del personaje de La vida y hechos..., cf. J. A. Cid, Máscaras y oficio en un escritor del Antiguo Régimen: Estebanillo González - Gabriel de la Vega (1988), 175-195.

"CUADERNOS DE ESTUDIOS GALLEGOS", Tomo XL, Fascículo 105, Santiago 1992. 
Quien visite hoy Salvatierra con la idea de evocar la villa que pudo conocer el pintor Lorenzo González antes de 1604, y la que pudo encontrar Estebanillo en un paréntesis de sus andanzas de romero medio tunante entre España y Portugal, en 1625, no hallará mucho campo para evocaciones seiscentistas de ningún tipo. La que en otro tiempo fue la plaza de armas de Galicia, ofrece poco de notable en sus construcciones, casi todas muy recientes, sin que el observador aprecie ningún plan coherente, antiguo ni moderno, en lo que no se ha derribado o se ha ido añadiendo. El propio castillo muy fuerte y muy hermoso, que convirtió la plaza en inexpugnable, según Gándara, es un conjunto de ruinas que hubieron de servir como cantera hasta hace bien poco, y del que ahora se procede a reconstruir algunos lienzos de la muralla que, si se desea, servirá de paredón para proyectar alguna iluminación nocturna, con el dudoso gusto que se ha hecho norma en tantos otros lugares. La iglesia, único edificio que los devanceiros del XVII podrían reconocer hoy, ha experimentado en su interior un remozamiento muy acorde con las tendencias de absoluta desnudez y sobriedad postconciliares, pero poco conformes a las formas de la religiosidad popular que han sido tradicionales en esta zona, tal como se reflejan en el libro de la cofradía de San Lorenzo.

El crecimiento de la villa ha sido anárquico, con abundancia de edificaciones despersonalizadas y ostentosas construidas sin excesivo respeto al entorno; en el exiguo centro urbano no faltan tampoco los desafueros tan absurdos como innecesarios. El contraste con la convecina Monçao, que ha sabido vertebrarse aprovechando las antiguas fortificaciones y ha mantenido un notable carácter en su parte antigua sin renunciar a crear espacios verdaderamente urbanos, no puede ser más desfavorable para la villa gallega. En fin, Salvatierra es un ejemplo más a añadir a lo que ha significado cierto tipo de desarrollismo en España, el de las décadas de 1960 en adelante, del que varias viejas poblaciones gallegas ofrecen algunas de las muestras más lamentables. Ya en otros terrenos, no puede dudarse que la villa experimenta hoy un notable empuje, y que la especulación de terrenos o la urbanización salvaje no son los únicos factores de ese empuje. Paradójicamente, son ahora los contactos con el antiguamente despreciado o temido rebelde portugués los que han contribuido a revitalizar la plaza fronteriza. El paso en trasbordador es continuo en ambas direcciones, y se halla muy avanzada la construcción de un puente sobre el Miño. Sólo hace unos años ese puente hubiera sido sencillamente inconcebible, y no por razones técnicas. Quien esto escribe tuvo ocasión, hacia 1963 o 1964, de conocer superficialmente

"CUADERNOS DE ESTUDIOS GALLEGOS", Tomo XL, Fascículo 105, Santiago 1992. 
a quien fue alcalde de Salvatierra durante bastante tiempo; lo recuerda como una persona afable y de gran corrección en su trato personal, que había pasado buena parte de su vida en Brasil, y que, sin embargo, expresaba recelos atávicos hacia sus vecinos de Potugal; unos recelos mucho más cercanos a los que experimentaban sus antepasados de 1660 que a la actitud de sus paisanos de hoy. Habrá que reconocer que en este sentido no todos los cambios han sido para peor.

Poco margen, pues, para rememoraciones historicistas en una Salvatierra volcada hacia un presente que ha borrado casi por completo la conciencia y la imagen puramente visual de lo que la villa fue en otro tiempo. El secretario del ayuntamiento, que nos atendió amablemente en alguna de las últimas visitas, es una de las pocas excepciones en el desinterés general por las antigüedades locales. En medio de llamadas telefónicas que parecen tener un objetivo único -la tramitación de licencias de obras- se duele de las tristes consecuencias que el incendio del archivo municipal, a principios de siglo, tuvo para la realización de posibles estudios históricos sobre Salvatierra y la comarca del Condado. Algunos jóvenes estudiantes de la villa han tenido que renunciar, por falta de documentación, a investigaciones que hubieran deseado realizar.

Por lo demás, la Casa de Cultura funciona más bien como almacén de bebidas y, ocasionalmente, como local para la vacunación de animales domésticos. La extraña sugerencia -expresada, es cierto, con poca convicciónde que tal vez pudiera pensarse en Esteban González para dar nombre a alguna de las nuevas calles cuando se agoten los de personalidades más recientes y conspicuas, tenía todo el aspecto de ser la salida de tono de un forastero excéntrico. Así es, sin duda, pero no por eso es menos verdad que no en todas partes han nacido personajes que dieran lugar a la que, según Juan Goytisolo, es la mejor novela española escrita en el siglo XVII (si exceptuamos, claro está, el Quijote). ${ }^{16}$

w $\quad$ w

He creído oportuno transcribir aquí, como única ilustración asequible de la intrahistoria de la Salvatierra del XVII, las páginas iniciales del libro de

${ }^{16} \mathrm{~J}$. Goytisolo, Estebanillo González, hombre de buen humor, Cuadernos de Ruedo Ibérico, 8 (1966), p. 80.

"CUADERNOS DE ESTUDIOS GALLEGOS", Tomo XL, Fascículo 105, Santiago 1992. 
la Cofradía de San Lorenzo. El vicario, Alonso Suares de Puga, y el escribano Domingo García de Tapia, al refundar la cofradía del santo patrón quisieron, además de dejar constancia de las terribles vicisitudes bélicas que la villa había acabado de padecer, restablecer los vínculos con el pasado anterior al largo exilio que los moradores habían sufrido. Esa solidaridad con el pasado se establecía en el imaginario colectivo a través del santo protector, pues por su intercesión se han recibido tan singulares beneficios generales y particulares de la mano de Dios y nos hallamos poseedores de tantos bienes espirituales y temporales, y vernos restituidos a nuestra patria; y se nos agrega el consuelo de sepultarnos en nuestra iglesia con nuestros pasados, que era un particular sentimiento que nos asistía.

Nada más natural que, para anudar los dos tiempos de la vida comunitaria separados por los dieciséis años de exilio, se recurra a narrar dos milagros del santo correspondientes a cada uno de esos tiempos. El redactor de las actas de la cofradía poseía ciertas dotes expresivas de buen narrador, y se permite a veces pequeños alardes estilísticos, como en la descripción de la tempestad, aplacada luego por el santo: Permitió Dios se rompiessen las cataratas del cielo con inundossíssimas aguas, truenos, relámpagos y granizos, que parecía se quería hundir este lugar; o el accidente sufrido por un artillero en el día de la fiesta de San Lorenzo, que el vicario narra como testigo de vista: $Y$ cuando miré al aire para encima del río y pareció veíamos volar los pedazos del cuerpo de Pedro das Obras [...] y cuando todos entendimos que iba volando por el aire hecho mostaza... . En este último milagro San Lorenzo muestra, de acuerdo con la interpretación del vicario, una excesiva y poco evangélica inclinación proespañola, pues, en el mismo cañonazo disparado por error, el santo no sólo causó este efeto y salvó la vida el artillero Pedro das Obras, sino que el mismo tiro ha muerto un soldado de a caballo del enemigo, de los que persiguían [a] los nuestros. Admitamos, antes de incurrir en fáciles ironías, que un santo patrono protector ha de serlo con todas sus consecuencias, y todos los efectos; y que para los salvaterranos de 1660 los campos de los nuestros y del enemigo estaban delimitados con una nitidez terrible, felizmente ya abolida. 


\section{IHS. 1660}

Libro y nueva fundación de la cofradía del glorioso martir San Lorenzo, único patrón desta iglesia, villa y feligresía de Salbatierra, después que las católicas armas de su Mgd. el Rey Don Felipe quarto, nuestro señor, la recuperaron del poder y tiranía del rebelde portugués, en quinze de febrero del año pasado de mil y seis cientos y cincuenta y nueve, abiéndola tiranizado en quinze de agosto de mill y ss ${ }^{0 s}$ y cuarenta y tres, siendo mayordomo de dicha cofradía Domingo García de Tapia, escribano de número y ayuntamiento de la dicha villa en [ ] de mill y seis cientos y sessenta y u[no].

$$
\text { - - } 1661-.
$$

En el nombre de la Santíssima Trinidad, padre, hijo y spíritu [sancto], unidivina excensia, que vive y reyna ssin principio ni fin, amen.

Sea notorio y manifiesto a todos los que al presente son, como a los que después de nós vinieren, que para el servicio de Dios nuestro señor, y de la Virgen santíssima, nuestra señora, y del glorioso mártir San Lorenzo, nuestro muy querido y amado patrón,

Nos el Licenciado Alonso Suares de Puga, vicario y cura perpetuo y propio desta iglesia parroquial y villa de Salbatierra; y Domingo García de Tapia, escribano de número y ayuntamiento de dicha villa; Pedro de Guillade; Pedro de Montes; Lorenzo Bas; Andrés Baz; Domingos Francisco; Lorenzo López, bezinos de dicha. villa, - - -

Geraldo Gonzales; Fernando Gonzalez; Fernando do Porto; Juan Gonzales; Pedro de Ssa; Juan de Montes, bezinos de la aldea del Casal, - - -

Simón de la Yglesia; Gregorio de Montes; Lorenzo López; Francisco Blanco; Pedro de Fontayña, bezinos de la aldea de Freixendo, - - -

Juan Pérez; Salbador de Souto; Domingo da Cuña; Alonso da Porta; Lorenzo González, vos. del lugar [de] Outeiriño, - - -

[ ] [Ló]pez; Alvaro Perez, bezinos del lugar de Ramallás, - - -

Estos feligreses y parroquianos de dicha Iglesia, villa y feligresía, por nós y los que después de nós vinieren, movidos con celo, fervor y devoción del servicio de Dios y la Virgen y de nuestro patrón San Lorenzo, acatando y teniendo muy presente la que antiguamente tenían nuestros padres y antecesores en servir al glorioso mártir, teniendo instituida su cofradía en esta santa 
iglesia, festejando y regocijando su día en hacimiento de graçias, haciendo otros servicios y dones que con buena voluntad hacían al glorioso santo por las singulares mercedes que por su intercesión alcanzaban de la mano de Dios nuestro señor, y que por medio suyo hacía evidentes milagros en los necesitados, enfermos y afligidos, de que aun al presente hay muy vivas memorias.

Y no sería justo que para nós ni para los que después de nós vinieren esté borrada la [memoria] de un tan particular milagro como el que subçedió antiguamente con la imagen del glorioso mártir, que llamaban San Lorenzo el viejo que estaba de bulto vestido en el altar mayor, que impiamente robó el dicho rebelde portugués, de cuya pérdida asiste correspondiente dolor en nuestros corazones. Y por ejemplo de dichos muchos y muy singulares milagros que Dios se sirvió obrar cọn los vecinos y naturales desta villa y su feligresía y otros en contorno [?], por intercesión de su siervo, se pone este aquí para mayor aumento de [¿la devoción?] y fervor de espíritu en el servicio de tan favorecido santo delante de Dios.

Fue, pues, el caso que subçediendo que el discurso del tiempo largo hiciese su operación en la madera de que estaba formada la imagen del glorioso martir San Lorenzo el viejo, que llegó la polilla o carcoma a causar imperfección en la cabeza y cara de la santa imagen. Con que subçediendo el vesitarse por el vesitador de iglesia, y reconoscido la dicha imagen, le pareció sería más decente enterrarle que tenerle en el altar. Resolviólo así y finalmente se hubo de enterrar en la iglesia vieja.

Y después de fenecida esta función, permitió Dios se rompiessen las cataratas del cielo con inundossíssimas aguas, truenos, relámpagos y granizos, que parecía se quería hundir este lugar, teniendo sus habitadores en aflición qual se puede considerar, sin cesar la furia en término de tres días. Con que ocurriendo a las últimas diligencias que deben hazer los católicos cristianos en el fin de sus vidas, les abrió discurso el Señor para hallar su remedio, por intercesión de su patrón; porque piadosamente creyeron que si se desenterrase la imagen, aplacaría nuestro Señor su yra contra ellos. Fueron, pues, llenos de lágrimas y en procesión al sepulcro de la santa imagen y la sacaron, limpiándola de la tierra, volviendo con ella al altar mayor, oficiando animosamente la misa y todos con la devoción que semejante caso pedía; con que súbitamente cesaron las aguas y tempestades, quedando el cielo claro y apacible, y todos tan alegres y gozosos como lo está el que se ve libre de las manos de la muerte.

"CUADERNOS DE ESTUDIOS GALLEGOS", Tomo XL, Fascículo 105, Santiago 1992. 
Y movidos en la santa devoción, y por desvanecer la indecencia que parecía causaba la imperfeción de la cabeza de la dicha imagen, acordaron se le hiziese otra de nuevo, y se vistiesse la imagen con su alba, dalmática y bonete, como le tocaba de diácono. Y con esta forma los mayordomos de su cofradía tenían cuidado de su adrezo y decencia, como siempre estaba en el altar mayor hasta que el Rebelde nos la quitó y Dios por nuestros pecados nos quiso privar deste bien, quedando desde entonzes con grande aumento la devoción de nuestro martir y patrón, acreciéndose con inumerables milagros que ordinariamente hacía y hace nuestro Señor por intercesión de su santo, que sería formar un proceso largo narrar los que aun hoy se hallan vivas las memorias de los presentes.

Y por que se conozca que aún a nuestra vista, y en este mismo año en su día, está obrando la Magestad divina milagros tan evidentes, supuesto que se ha dicho uno de los antiguos, ha parecido justo referir de ahora alguno, para que con mayor devoción nos animemos y se animen nuestros sucesores a servir al glorioso santo.

Sucedió así: hallándose el ejército de su Magestad, que gobierna el señor Marqués de Viana, sobre Valencia del Miño, salieron unos soldados a hazer una partida por las faldas de las montañas de Cocera. Aprehendieron una presa de ganado y fueron cargados del enemigo. Y no pudiendo volverse al ejército, se vinieron retirando con la presa al abrigo desta plaza; y hasta las orillas del Miño fueron persiguidos a nuestra vista.

Y habiéndose aprestado un cañón de artillería para disparar al enemigo, después de tenerle asestado quiso Pedro das Obras, artillero, ir a tomar el botafogo que estaba en el suelo junto a la boca de la pieza; y estando con el cuerpo delante della, con la priessa de disparar al enemigo, Antonio de Campo, cerrajero, que a este tiempo tenía otro botafuego en la mano, sin reparar que el otro estaba delante atravessado en la boca de la misma pieza, le dio fuego. Y visto por mí, dicho vicario, que me hallé pressente con otros muchos, el manifiesto peligro, con agonía y fervor de corazón invoqué al glorioso mártir San Lorenzo que le socorriesse.Y cuando miré al aire para encima del río y pareció veíamos volar los pedazos del cuerpo de Pedro das Obras, quiso Dios librarle por intercesión de su santo para que en su día no sucediese tal desdicha y desconsuelo; porque al mismo tiempo que se dio el fuego en el fogón de la pieza a el mismo le inspiró Nuestro Señor que se bajase por el botafuego que estaba en el suelo; y, bajándose, salío la pieza y, levantándose con su insignia, acababa de salir la carga, quedando todo lleno de

"CUADERNOS DE ESTUDIOS GALLEGOS", Tomo XL, Fascículo 105, Santiago 1992. 
fuego en la cabeza y por el cuerpo, de los retazos del taco de la pieza que le cayeron encima cuando se bajó por el botafuego.

Y cuando todos entendimos que iba volando por el aire hecho mostaza, se levantó sano y salvo preguntando cuál había sido el que había echado fuego a la pieza, quedando todos maravillados, atónitos y como sin sentido, si bien alegres de verle vivo, dando infinitas gracias a nuestro abogado, diciendo a voces el milagro.

Y no sólo causó este efeto, porque el mismo tiro ha muerto un soldado de a caballo del enemigo, de los que persiguían los nuestros, que estaba sobre la Boa vista [?].

En esta atención, pues, y considerando que los libros desta santa cofradía los robó el rebelde cuando se apoderó desta villa; y porque no sería justo dejar de volver a formarla y servir a nuestro santo patrón, pues Dios por su intercesión se quiso servir hacernos tantas mercedes, apiadándose de nosotros, y volvernos a nuestra patria y villa de Salbatierra, acordamos de servir de buen corazón a nuestro patrón y que se vuelva a hacer fundación de su cofradía con las instituciones y gravámenes siguientes para su conservación y aumento y bien de nuestras almas y de nuestros subcesores, y que todo sea para mayor servicio, honra y gloria de Dios nuestro Señor, amen.

[Siguen las Constituciones de la cofradía. Se reglamentan en ellas con todo detalle las obligaciones y derechos de los cofrades, y especialmente los deberes del mayordomo y capellanes. Se trata también de las festividades en honor del santo, con procesiones y misas solemnes, y del cuidado o restablecimiento del patrimonio de la cofradía, en el que se incluía el pendón del glorioso santo y su cofradía, pendón que tenía una cruz de plata, la cual con otras piezas de la iglesia robó el rebelde portugués y quedó el pendón sin ella, por lo que se acordó que luego que la cofradía tenga caudal se le haga otra cruz de plata, lucida y de buena hechura. También se dispone que una casa en la calle del medio, propiedad del glorioso San Lorenzo, fuera mantenida habitada, como lo estuvo antes de la ruina desta villa. Se dan informaciones ocasionales sobre los mayordomos y donaciones recibidas antes de la conquista portuguesa, y parece evidente la relación que los condes de Salvatierra mantuvieron con la cofradía.

A las constituciones acompaña la aprobación y confirmación del obispo de Tuy, Antonio Fernández del Campo Angulo y Velasco, quien las ratifica en julio de 1668, sin perjuicio de nuestra jurisdición y reservándose el derecho episcopal de visitar la dicha cofradía y tomar cuentas del mayor-

"CUADERNOS DE ESTUDIOS GALLEGOS", Tomo XL, Fascículo 105, Santiago 1992. 
domo que fuese, y que si en algún tiempo nos o nuestros sucesores quisiéremos añadir, quitar o alterar algunos capítulos de los aquí contenidos lo podamos hacer, y si los dichos cofrades lo quisieren hacer sea con aprobación y licencia nuestra o de nuestros sucesores, y no de otra manera.

El resto del libro consta de la anotación de las ofrendas en metálico y, sobre todo, en especie (con el celemín de trigo como unidad de cuenta) que los cofrades se obligaban a donar como entrada y anualidad]. 